\section{Loyalitas Kreativitas \\ Aldi Masyarakat Kreatif}

P-ISSN 2722-2101, E-ISSN 2722-4201

Program Studi Ekonomi Manajemen Universitas Pamulang

Jurnal LOKABMAS Kreatif Vol.02,No.02.Juli 2021 Hal.28-34

Email:jurnalkreatif.manajemen@gmail.com

\title{
PENERAPAN STANDARISASI LAPORAN KEUANGAN UMKM BAGI PENGUSAHA KECIL MENENGAH UNTUK MENINGKATKAN KINERJA USAHA PADA UMKM MERTA JASA
}

Shelby Virby, Jublina Oktora, Nurwita, Styo Budi Utomo, Intan Sari Budhiarjo.

\author{
Dosen Ekonomi Fakultas Ekonomi Akutansi Universitas Pamulang \\ Email dosen@unpam.ac.id, dosen01887@unpam.ac.id, dosen@unpam.ac.id, \\ dosen@unpam.ac.id, dosen@unpam.ac.id.
}

\begin{abstract}
ABSTRAK
Tujuan dari Kegiatan Pengabdian Kepada Masyarakat adalah untuk melaksanakan salah satu Tri Darma Perguruan Tinggi. Selain itu diharapkan dengan pengabdian kepada masyarakat tersebut keberadaan perguruan tinggi dapat memberikan kontribusi besar kepada pengembangan dan penerapan keilmuan kepada masyarakat.

Metode yang digunakan pada Pengabdian Kepada Masyarakat ini berupa penyampaian materi secara verbal dan pembelajaran yang menekankan pada proses berpikir kritis dan analitis terkait keilmuan manajemen keuangan, manajemen sumber daya manusia dan juga pengembangannya (pelaku usaha mikro kecil menengah)

Sesuai dengan Undang - undang nomor 20 tahun 2008 tentang usaha mikro, kecil dan menengah (UMKM). Usaha mikro adalah usaha produktif milik orang perorangan dan/atau badan usaha perorangan yang memenuhi kriteria usaha mikro sebagaimana diatur dalam Undang-Undang ini.

Usaha Kecil adalah usaha ekonomi produktif yang berdiri sendiri, yang dilakukan oleh orang perorangan atau badan usaha yang bukan merupakan anak perusahaan atau bukan cabang perusahaan yang dimiliki, dikuasai, atau menjadi bagian baik langsung maupun tidak langsung dari usaha menengah atau usaha besar yang memenuhi kriteria usaha kecil sebagaimana dimaksud dalam Undang-Undang ini.

Usaha menengah adalah usaha ekonomi produktif yang berdiri sendiri, yang dilakukan oleh orang perseorangan atau badan usaha yang bukan merupakan anak perusahaan atau cabang perusahaan yang dimiliki, dikuasai, atau menjadi bagian baik langsung maupun tidak langsung dengan usaha kecil atau usaha besar dengan jumlah kekayaan bersih atau hasil penjualan tahunan sebagaimana diatur dalam Undang-Undang ini.

Hingga saat ini, jumlah pengusaha UMKM di Indonesia mengalami kenaikan yang sangat signifikan. Namun hal yang sangat membanggakan ini hanya dilihat dari sisi kuantitas tanpa melihat dari sisi kualitas usaha, khususnya dari aspek finansial. Oleh karena itu kami ingin kegiatan PKM dilaksanakan untuk meningkatkan kuantitas, kinerja juga finansial UMKM Merta Jasa di desa belega.
\end{abstract}

\section{Kata Kunci: Laporan Keuangan, Kuantitas Dan Kinerja UMKM}




\section{Loyalitas Kreativitas \\ Aldi Masyarakat Kreatif}

P-ISSN 2722-2101, E-ISSN 2722-4201

Program Studi Ekonomi Manajemen Universitas Pamulang

Jurnal LOKABMAS Kreatif Vol.02,No.02.Juli 2021 Hal.28-34

Email:jurnalkreatif.manajemen@gmail.com

\begin{abstract}
The purpose of community service activities is to carry out one of the tri darma of higher education. In addition, it is hoped that with this community service, the existence of universities can make a major contribution to the development and application of science to the community.

The method used in this community service is in the form of verbal delivery of material and learning that emphasizes critical and analytical thinking processes related to financial management, human resource management and also its development (micro, small and medium enterprises).

In accordance with law number 20 of 2008 concerning micro, small and medium enterprises (UMKM). A micro business is a productive business owned by an individual business entity that meets the criteria for a micro business as regulated in this law.

Small business is a productive economic business that stands alone, which is carried out by an individual or business entity that is not a subsidiary or branch of a company that is owned, controlled or part of, either directly or indirectly, form a medium or large business that meets the criteria of a small business as referred to in this law.

Medium-sized business is a stand-alone productive economic enterprise, conducted by an individual or business entity that is not a subsidiary or branch of a company owned, controlled, or part of either directly or indirectly with a small business or large business with the amount of net worth or annual sales proceeds as stipulated in this Law.

Until now, the number of MSME entrepreneurs in Indonesia has increased significantly. But this very proud thing is only seen in terms of quantity without looking at the quality of the business, especially from the financial aspect. Therefore, we want PKM activities to be carried out to increase the quantity, performance and financial of UMKM Merta Jasa in belega village.
\end{abstract}

Keywords: Financial Report, Quantity and Performance of UMKM.

\section{PENDAHULUAN}

Dikarenakan pengusaha UMKM memperhatikan pengelolaan keuangan demi kemajuan usahanya, padahal pengelolaan keuangan merupakan aspek utama dalam memajukan usaha. Pengelolaan keuangan dapat dilakukan dengan laporan keuangan (Akuntansi) usaha sederhana. Akuntansi adalah metode pencatatan secara sistematis yang menyajikan proses laju keuangan secara sistematis guna menghasilkan informasi keuangan dalam pengambilan keputusan bagi pengguna dari laporan keuangan tersebut.

Sepanjang uang digunakan oleh para pengusaha UMKM sebagai alat tukar, para pengusaha UMKM membutuhkan laporan akuntansi. Manfaat laporan akuntansi terhadap para pelaku UMKM, antara lain: (1) UMKM dapat mengetahui kinerja keuangan perusahaan, (2) UMKM dapat mengetahui, memilah, dan membedakan harta perusahaan dan harta pemilik, (3) UMKM dapat mengetahui posisi dana baik sumber maupun penggunaannya, (4) UMKM dapat membuat anggaran yang tepat, (5) UMKM dapat menghitung pajak, (6) UMKM dapat mengetahui aliran uang tunai selama periode tertentu, dan (7) dapat meyakinkan pihak lembaga keuangan dalam memberikan bantuan modal usaha bagi UMKM. Pengertian Akuntansi, menurut Abubakar A \& Wibowo (2004), adalah proses identifikasi, pencatatan dan komunikasi terhadap transaksi ekonomi dari suatu 
Loyalitas Kreativitas

Aldi Masyarakat Kreatif
P-ISSN 2722-2101, E-ISSN 2722-4201

Program Studi Ekonomi Manajemen Universitas Pamulang

Jurnal LOKABMAS Kreatif Vol.02,No.02.Juli 2021 Hal.28-34

Email:jurnalkreatif.manajemen@gmail.com entitas/perusahaan.

Akuntansi

merupakan kegiatan proses analisis keuangan yang memiliki 3 kegiatan utama yaitu: pertama, aktivitas identifikasi merupakan kegiatan mengidentifikasikan transaksi-transaksi yang terjadi dalam perusahaan. Kedua, aktivitas pencatatan adalah aktivitas yang mencatat berbagai transaksi yang telah diidentifikasi secara kronologis dan sistematis. Aktivitas ketiga adalah komunikasi yaitu informasi akuntansi yang dikomunikasikan dalam bentuk laporan keuangan kepada pihak yang berkepentingan baik internal perusahaan maupun pihak eksternal pelaku usaha.

Akuntansi seringkali digunakan oleh perusahaan berguna untuk memberikan informasi yang berupa datadata keuangan perusahaan guna pengambilan keputusan perusahaan. Dalam menjalankan aktivitas sehari-hari, diperlukan beberapa informasi khususnya di bidang keuangan, diantaranya informasi nilai perusahaan dan informasi laba/rugi perusahaan. Kedua informasi tersebut diperlukan untuk mengetahui seberapa besar perusahaan memiliki modal, perkembangan atau maju mundurnya keuangan perusahaan dapat diketahui, sebagai dasar untuk perhitungan pajak, dapat diketahui kondisi perusahaan saat dibutuhkan memerlukan loan dari bank atau pihak lain, sebagai dasar untuk menentukan kebijakan yang akan ditempuh perusahaan, Menarik minat investor saham jika perusahaan berbentuk PT (Perseroan Terbatas).

Jika Akuntansi sebagai suatu sistem, di dalam akuntansi terdapat berbagai konsep pemikiran dasar keuangan. Asumsi dasar tersebut antara lain: Business Entity, asumsi pemikiran ini beranggapan jika aktiva suatu perusahaan harus dipisahkan dari aktiva orang pribadi yang menyediakan aktiva (modal) untuk dipergunakan dalam operasional perusahaan tersebut.
Dalam ilmu akuntansi, dalam pembukuan laporan keuangan perusahaan mengeluarkan berbagai definisi dari konsep kesatuan usaha, utang dan biaya pribadi pemilik ketika pemilik usaha memiliki aktiva, utang dan pendapatan perusahaan sehingga segala utang dan biaya pribadi harus diperhitungkan terpisah dari perusahaan. Kedua asumsi Going Concern, Dalam konsep ini dalam jangka waktu tertentu perusahaan berdiri dan beroperasional contohnya perusahaan yang ingin mendirikan perusahaannya menjadi berbentuk Perseroan Terbatas di Indonesia membutuhkan waktu 75 tahun sehingga tercipta asumsi bahwa selama watu tersebut perusahaan masih tetap beroperasional dan menghasilkan keuntungan, maka perusahaan yang dimiliki dapat beroperasional secara terus menerus dalam waktu yang tidak terbatas.

Asumsi berikutnya adalah Time Periods, dalam menjalankan operasional perusahaan hendaknya mempertimbangkan berbagai hal sebagai landasan dalam pengambilan keputusan baik berdasarkan pemikiran para stakeholder maupun stockholder perusahaan yang berkepentingan selama berlangsungnya operasional perusahaan. Untuk menampung hal tersebut, perusahaan hendaknya membuat laporan keuangan perusahaan untuk jangka waktu satu tahun transaksi operasional perusahaan. Keempat yaitu Money Measurement, Semua transaksi perusahaan dicatat dan dapat diukur dengan satuan tertentu contohnya Rp., \$, Ruppee, Bath, dll.

Kelima, Harta Perolehan (Costing of Assets) adalah seluruh aktiva pada umumnya dibukukan sebesar harga perolehannya. Asumsi berikutnya adalah Dual Aspect yaitu setiap pencatatan suatu kejadian atau transaksi akan berpengaruh pada sedikitnya dua akun perkiraan dalam pembukuan. Asumsi keenam 
adalah Accrual Concept, Asumsi ini merupakan perhitungan laba/rugi perusahaan yang menekankan suatu kejadian pada suatu periode tertentu baik merupakan biaya maupun hasil. Jika para pengusaha UMKM memahami akan pentingnya akuntansi dalam menjalankan usahanya.

Pengusaha UMKM pasti akan selalu menjadikan pedoman dasar dalam melakukan perencanaan usaha. Karena dengan akuntansi, UMKM dapat mengetahui berbagai hal yang diperbuat ketika mengalami kerugian dan laba. Ketika laba yang diperoleh semakin meningkat dengan tata kelola keuangan yang baik, maka UMKM dapat menjadi solusi utama bagi pemerintah bagi berbagai permasalahan perekonomian.

Pelaku UMKM Merta Jasa berada di Kelurahan Desa Belega yang beralamat di Desa Belega, Kabupaten Gianyar. Mereka belum memiliki kesadaran tentang tata kelola keuangan usaha kecil yang sesuai standar akuntansi sederhana yang khususnya mengenai manajemen keuangan dan manajemen bank dan pengetahuan mengenai bank dan non lembaga keuangan.

\section{B. GAMBARAN UMUM SITUASI}

Salah satu cara untuk meningkatkan kesejahteraan masyarakat adalah dengan melakukan wirausaha, karena dengan wirausaha akan membuat masyarakat menjadi mandiri dan membuka peluang untuk dirinya sendiri. Hakikat setiap usaha didirikan yaitu untuk mencapai suatu tujuan tertentu.

Suatu kegiatan operasional usaha atau perusahaan, maka diperlukan adanya penyusunan laporan keuangan. Hasil dari penyusunan laporan keuangan adalah berupa informasi yang dapat digunakan untuk menunjukkan kondisi keuangan (Suhairi, 2004).

UMKM Merta Jasa sudah lama menjalankan kegiatan operasionalnya. Maka sangat diperlukan laporan keuangan yang valid. Definisi laporan keuangan adalah catatan informasi keuangan suatu perusahaan pada periode akuntansi yang menggambarkan kinerja perusahaan tersebut. Laporan keuangan berguna bagi bankir, kreditor, pemilik dan pihak pihak yang berkepentingan dalam menganalisis serta menginterpretasikan kinerja keuangan dan kondisi perusahaan (Ikatan Akuntansi Indonesia, 2009).

Informasi keuangan yang digunakan oleh bank untuk menginterpretasikan kemampuan UMKM dalam mengelola dana dan memprediksi resiko kegagalan usaha yang dijalankan karena ketidakmampuan UMKM dalam mengelola dana.

Setelah mengetahui aktivitas keuangan yang ada maka peneliti dapat memulai untuk melakukan penyusunan laporan keuangan yang sesuai dengan standar akuntansi keuangan usaha mikro, kecil dan menengah pada Merta Jasa.

\section{RUMUSAN MASALAH}

Adapun rumusan masalah dalam PKM ini adalah:

1. Apakah standarisasi laporan keuangan mempunyai pengaruh terhadap peningkatan kuantitas finansial para pelaku UMKM Merta Jasa?

2. Apakah penerapan standarisasi laporan keuangan mempunyai pengaruh terhadap kinerja usaha para pelaku UMKM Merta Jasa?

\section{TUJUAN PELAKSANAAN}

Adapun tujuan dari kegiatan Pengabdian Kepada Masyarakat adalah:

1. Untuk mengetahui apakah penerapan standarisasi laporan keuangan berpengaruh terhadap peningkatan kuantitas fnansial para pelaku UMKM Merta Jasa.

2. Untuk mengetahui apakah penerapan standarisasi laporan keuangan berpengaruh terhadap kinerja usaha para pelaku UMKM Merta Jasa.

\section{TINJAUAN PUSTAKA}

Ikatan Akuntansi Indonesia telah mengesahkan Exposure Draft Standar Akuntansi Keuangan Entitas Mikro, Kecil dan Menengah ("Exposure Draft SAK 
Loyalitas Kreativitas

Aldi Masyarakat Kreatif
P-ISSN 2722-2101, E-ISSN 2722-4201

Program Studi Ekonomi Manajemen Universitas Pamulang

Jurnal LOKABMAS Kreatif Vol.02,No.02.Juli 2021 Hal.28-34

Email:jurnalkreatif.manajemen@gmail.com
EMKM") dalam rapatnya pada tanggal 18 Mei 2016 dan berlaku efektif 1 Januari 2018. Exposure Draft SAK EMKM ini merupakan standar akuntansi keuangan yang jauh lebih sederhana bila dibandingkan dengan SAK ETAP. Diterbitkannya SAK EMKM bertujuan untuk implementasikan pada entitas mikro, kecil dan menengah (tanpa akuntabilitas publik yang signifikan, sebagaimana didefinisikan dalam Standar Akuntansi Keuangan Entitas Tanpa Akuntabilitas Publik (SAK ETAP), yang memenuhi definisi dan kriteria usaha mikro, kecil dan menengah sebagaimana diatur dalam peraturan perundang-undangan yang berlaku di Indonesia. Adapun kriterianya adalah

1. Kriteria usaha mikro adalah sebagai berikut

a. Memiliki kekayaan bersih paling banyak Rp. 50.000.000,00 (lima puluh juta rupiah) tidak termasuk tanah dan bangunan tempat usaha; atau memiliki hasil penjualan tahunan paling banyak Rp. 300.000.000,00 (tiga ratus juta rupiah).

2. Kriteria usaha kecil adalah sebagai berikut

a. Memiliki kekayaan bersih lebih dari Rp. 50.000.000,00 (lima puluh juta rupiah) sampai dengan paling banyak Rp. 500.000.000,00 (lima ratus juta rupiah) tidak termasuk tanah dan bangunan tempat usaha; atau memiliki hasil penjualan tahunan lebih dari Rp. 300.000.000,00 (tiga ratus juta rupiah) sampai dengan paling banyak Rp. 2.500.000.000,00 (dua milyar lima ratus juta rupiah).

3. Kriteria usaha menengah adalah sebagai berikut

a. Memiliki kekayaan bersih lebih dari Rp. 500.000.000,00 (lima ratus juta rupiah) sampai dengan paling banyak Rp. 10.000.000.000,00 (sepuluh milyar rupiah) tidak termasuk tanah dan bangunan tempat usaha; atau memiliki hasil penjualan tahunan lebih dari Rp.
2.500.000.000,00 (dua milyar lima ratus juta rupiah) sampai dengan paling banyak $\mathrm{Rp}$. 50.000.000.000,00 (lima puluh milyar rupiah)

4. Kriteria sebagaimana dimaksud pada ayat 1 huruf a dan ayat 2 huruf a, serta ayat 3 huruf a, nilai nominalnya dapat diubah sesuai dengan perkembangan perekonomian yang diatur dalam Peraturan Presiden.

\section{HASIL DAN PEMBAHASAN}

Hasil pelaksanaan kegiatan pengabdian pada masyarakat adalah sebagai berikut:

1) Pelaksanaan Kegiatan Pengabdian Pada Masyarakat ini dilakukan di desa belega, bali. Kegiatan tersebut dijabarkan sebagai berikut:

a) Acara diawali dengan pengenalan tentang apa itu konsep manajemen.

b) Kemudian dilanjutkan dengan ceramah tentang manajemen keuangan, akuntansi dan manajemen sumber daya manusia.

c) Para peserta diberikan sebuah tayangan yang menggambarkan Trik-trik dan strategi meningkatkan kinerja dan laporan keuangan.

d) Setelah sesi ceramah dan demonstrasi tayangan, dilanjutkan dengan sharing mengenai laporan keuangan sesuai standar akuntansi.

2. Hasil Kegiatan Pengabdian Kepada Masyarakat Hasil Kegiatan Pengabdian Pada Masyarakat antara lain adalah sebagai berikut:

a) Pada sesi ceramah dibuka kesempatan untuk berdiskusi, di mana melihat pemahaman Masyarakat Desa Belega yang baru mengenal secara terperinci mengenai laporan keuangan. Sehingga penjelasan dalam sesi diskusi ini memberikan pengetahuan baru kepada mereka.

b) Sesi ceramah dan diskusi berjalan sangat kondusif, para peserta dengan antusias mengikuti sesi pelatihan. Saat demonstrasi video, para peserta memperhatikan dengan seksama.

c) Pada sesi sharing diambil 7 Orang dari Masyarakat Desa Belega untuk 
menjabarkan sistem laporan keuangan yang digunakan.

\section{KESIMPULAN DAN SARAN Kesimpulan}

Berdasarkan pemaparan hasil pelaksanaan kegiatan pengabdian pada masyarakat dan pembahasannya, maka dapat disampaikan kesimpulan sebagai berikut:

1. Kegiatan PKM ini membuka cakrawala pengetahuan masyarakat desa belega mengenai konsep Manajemen.

2. PKM ini memungkinkan organisasi untuk menanggapi peluang eksternal atau internal dan menggunakan kreativitas untuk memperkenalkan ide-ide, proses, atau produk yang ditindaklanjuti oleh masyarakat desa belega.

3. Kinerja masyarakat desa belega mempunyai peranan yang sangat penting dalam meningkatkan kesejahteraan nasional. Tidak ada jenis kegiatan manusia yang tidak mendapatkan keuntungan dari produktivitas yang ditingkatkan sebagai kekuataan untuk menghasilkan lebih banyak barang barang maupun jasa jasa.

\section{Saran}

Ketika kegiatan pengabdian kepada masyarakat ini dapat dilaksanakan, kami berharap para peserta pelatihan ini merasakan benefit yang sangat besar. Hal ini dikarenakan para peserta memperoleh banyak pengetahuan dan praktik mengenai penyusunan laporan keuangan sederhana bagi pengusaha kecil dan menengah.

Koordinasi dan kerjasama yang dilakukan antara dosen Unpam dalam hal ini pelaksana kegiatan pengabdian masyarakat di desa belega diharapkan akan sangat baik. Pihak UMKM di desa belega sangat menyambut dengan baik kegiatan yang dapat meningkatkan kemampuan para pelaku UMKM.

Pertanyaan dan diskusi yang dilakukan dapat dibahas secara mendalam karena adanya waktu pelaksanaan kegiatan mengenai tata cara kelola usaha (manajemen usaha), pengetahuan mengenai lembaga keuangan (Perbankan dan Non Perbankan plat merah maupun non plat merah) terutama mengenai tata cara atau peraturan terbaru mengenai pengajuan modal usaha dengan baik dan benar. Selain itu, pembuatan laporan keuangan sesuai standar akuntansi sederhana untuk masing-masing usaha yang mempunyai karakteristik yang berbeda, dapat didiskusikan secara maksimal. Saat mengadakan kegiatan serupa berikutnya, diperlukan kegiatan pendampingan pembuatan laporan keuangan akuntansi sederhana bagi UMKM yang masih kesulitan membuat laporan keuangan usaha tersebut.

Sumber daya manusia memegang peranan penting dalam setiap kegiatan, termasuk kegiatan suatu organisasi. Organisasi di saat era globalisasi memerlukan suatu percepatan dalam pengembangan usahanya, agar tidak tertinggal dengan organisasi lainnya.

Untuk meningkatkan kinerja usaha maka harus dilaksanakan evaluasi secara rutin. Tujuannya agar adanya peningkatan kinerja usaha. Jika para pelaku UMKM mengalami penurunan kinerja, maka harus segera memperbaikinya dengan memberikan pelatihan dan program pengembangan diri.

Dalam penelitian ini ada variabel yang harus dianalisis yaitu laporan keuangan dan kinerja usaha. Untuk menganalisis data maka kami melakukan penelusuran melalui catatan lapangan dan hasil wawancara, seperti

1. Pengumpulan informasi melalui pengamatan, wawancara dan dokumentasi

2. Pemusatan perhatian pada laporan keuangan dan kinerja usaha yang muncul di lapangan.

3. Penyajian data diarahkan agar data yang dihasilkan mencapai analisis 
Loyalitas Kreativitas

Aldi Masyarakat Kreatif
P-ISSN 2722-2101, E-ISSN 2722-4201

Program Studi Ekonomi Manajemen Universitas Pamulang Jurnal LOKABMAS Kreatif Vol.02,No.02.Juli 2021 Hal.28-34 Email:jurnalkreatif.manajemen@gmail.com kualitatif dan kuantitatif yang valid dan handal.

\section{DAFTAR PUSTAKA}

Abubakar, Arif \& Wibowo. 2004. Akuntansi Untuk Bisnis Usaha Kecil dan Menengah. Jakarta: Penerbit PT. Grasindo.

Elburdah, R. P., Pasaribu, V. L. D., Rahayu, S., Septiani, F., \& Metarini, R. R. A. (2021). Mompreneur Penopang Perekonomian Keluarga Di Masa Pandemi Covid-19 Dengan Bisnis Online Pada Kelurahan Pondok Benda. Abdi Laksana: Jurnal Pengabdian Kepada Masyarakat, 2(1), 75-82.

Eko Suparno. 2014. Manajemen Pengembangan Sumber Daya Manusia. Jakarta: Ardadizya Jaya.

Lestari, N.P.N.E. 2014. Strategi Pemberdayaan Industri Kecil Kerajinan Ukiran Kayu di kabupaten Gianyar Provinsi Bali. Bali: Universitas Udayana Press: http://www.scribd.com/doc/29577478 2/Unud-79-1104976961-Disertasi-NiPutu-Nina-Eka-Lestari-1090671010

Luthan Fred. 2011. Organizational Behavior: An Evidence-Based Approach. New York: McGraw-Hill.

Pasaribu, V. L. D., Agrasadya, A., Shabrina, N., \& Krisnaldy, K. (2020). Menjadi Enterpreneur Muda Yang Memiliki Jiwa Leadership Untuk Menghadapi Masa Depan. Abdi Laksana: Jurnal Pengabdian Kepada Masyarakat, 1(1).

Pasaribu, V. L. D., Susanti, F., \& Hartuti, E. T. K. (2019). Memotivasi Siswa dan Siswi SMK Letris Indonesia di Dalam Menentukan Pilihan Untuk
Melanjutkan Pendidikan Atau Bekerja Setelah Lulus Sekolah. Jurnal Pengabdian Dharma Laksana, 1(2), 161-172.

Pasaribu, V. L. D., Sulaiman, S., Sutiman, S., Thaharudin, T., \& Purnomo, B. Y. (2020). Pengenalan Letak Posyandu Terdekat Dikelurahan Pisangan Dengan Manajemen Pemasaran Revolusi 4.0 Untuk Meningkatkan Pengetahuan Masyarakat Letak Dan Fungsi Posyandu Terdekat Pada Kelurahan Pisangan. Dedikasi Pkm, l(1), 105-110.

Pasaribu, V. L. D., Oktrima, B., Prabowo, B., Arianto, N., \& Haryoko, U. B. (2020). Progam Pendampingan Dan Penyelenggaraan Pendidikan Anak Pada Usia Dini Terhadap Prestasi Belajar Dilingkungan Rt $020 \mathrm{Rw}$ 009. Kel Giri Peni. Kec Wates. Yogyakarta. Jurnal Lokabmas Kreatif, 1(1), 71-75.

Pasaribu, V. L. D., Jannah, M., Fazar, M., Putra, S. P., Monalisa, M., \& Sofa, M. (2021). MENINGKATKAN PRODUKTIVITAS USAHA DIMASA PANDEMI PADA IBU PKK RT 004/003 KELURAHAN SAWAH BARU CIPUTAT, TANGERANG SELATAN. Abdi Laksana: Jurnal Pengabdian Kepada Masyarakat, 2(2), 295-301.

Pasaribu, V. L. D., Yuniati, H. L., Pranata, R., Sembayu, R., Purba, S. M., \& Nurbayani, T. T. A. (2021). MANAJEMEN KEUANGAN UNTUK MENGHADAPI DAN BERTAHAN DI ERA COVID 19. Jurnal Abdimas Tri Dharma Manajemen, 2(2), 12-18.

Pasaribu, V. L. D., Dwiyatni, A., Sabina, C., Ridwan, M., Gunawan, D. D., \& Noviani, B. C. (2021). EVALUASI PENERAPAN 3M DIMASA PANDEMIC COVID 19. Jurnal Abdimas Tri Dharma Manajemen, 2(2), 54-60. 
Loyalitas Kreativitas

Aldi Masyarakat Kreatif
P-ISSN 2722-2101, E-ISSN 2722-4201

Program Studi Ekonomi Manajemen Universitas Pamulang Jurnal LOKABMAS Kreatif Vol.02,No.02.Juli 2021 Hal.28-34 Email:jurnalkreatif.manajemen@gmail.com
Pasaribu, V. L. D., Syafei, A. N., Farhan, A., Aufaizah, A., Irani, C., \& Firtiayani, S. R. (2021). PENGARUH DISPLIN PROTOKOL KESEHATAN TERHADAP PENCEGAHAN PENULARAN VIRUS COVID-19. Jurnal Abdimas Tri Dharma Manajemen, 2(2), 91-98.

Priadi, A., Pasaribu, V. L. D., Virby, S., Sairin, S., \& Wardani, W. G. (2020). Penguatan Ekonomi Kreatif Berbasis Sumber Daya Desa Dikelurahan Rempoa. Abdi Laksana: Jurnal Pengabdian Kepada Masyarakat, 1(3), 356-35

Sudaryono. 2014. Leadership: Teori dan Praktek Kepemimpinan. Jakarta Pusat: Lentera Ilmu Cendekia.

Suhairi. 2004. Personality, Accounting Knowledge, Accounting Information Usage and Performance A Research On Entrepreneurship of Indonesia Medium Industries, Disertasi. USM, Malaysia.

---2006. Persepsi Akuntansi Terhadap Overload Standar Akuntansi Keuangan (SAK) Bagi Usaha Kecil dan Menengah. Makalah yang disampaikan pada SNAIX Padang.

Uhar Suharsaputra. 2013. Administrasi Pendidikan. Bandung: PT. Refika Aditama.

Widodo. 2017. Metodologi Penelitian Populer dan Praktis. Depok: PT. Raja Grafindo Persada.

Wina Sanjaya. 2013. Strategi Pembelajaran Berorientasi Standar Proses Pendidikan. Jakarta: Kencana Prenadamedia Group.

\section{DOKUMENTASI KEGIATAN}
